\title{
Screening of Brinjal Hybrids for Resistance to Brinjal Shoot and Fruit Borer, Leucinodes orbonalis (G.)
}

\author{
Vinay Kavishetti* and C. Lekha Rani
}

Department of Plant Breeding and Genetics, College of Agriculture (KAU), Vellayani, Thiruvanthapuram, Kerala-695522, India

*Corresponding author

Key w o r d s
$\begin{aligned} & \text { Brinjal, Shoot and } \\ & \text { fruit borer, Hybrids }\end{aligned}$
Article Info
Accepted:
20 January 2018
Available Online:
10 February 2018

\section{A B S T R A C T}

The present studies on screening of eleven brinjal hybrids against brinjal shoot and fruit borer, Leucinodes orbonalis (G.) was carried out during 2015-16 and 2016-17 at College of Agriculture, Vellayani, Trivandrum in kharif and summer seasons. The study revealed that the hybrids Swetha $\mathrm{x}$ Vellayani local, Neelima and Wardha local $\mathrm{x}$ Palakurthi local were found to be moderately resistant with minimum shoot infestation in both the seasons while maximum shoot infestation was recorded in hybrids NBR-38 x Vellayani local and NBR-38 x Selection Pooja. Minimum infestation in fruits was found in Swetha $x$ Vellayani local, Neelima and Wardha local $x$ Palakurthi local while maximum infestation in fruits was recorded in NBR38 x Selection Pooja, Wardha local x Vellayani local and Wardha local x Surya.

\section{Introduction}

Brinjal (Solanum melongena L.) being native to India, is one of the most common vegetable crops of the country. Based upon its highest production potential and availability of the produce to consumers, it is also termed as 'poor man's vegetable'. The production of brinjal suffers immensely due to the attack of disease and insect pests. Brinjal is subjected to attack by a number of insect and non-insect pests from nursery stage to harvest. The most extensive pest of this vegetable is brinjal shoot and fruit borer (L. orbonalis) which reduces the yield and inflicts colossal loss in production. The losses caused by the pest vary from season to season because moderate temperature and high humidity favour the population build-up of brinjal shoot and fruit borer (Shukla and Khatri, 2010; Bhushan et al., 2011). This pest may reduce the crop yield upto 60-70\% (Singh and Nath, 2010).

Indiscriminate use of synthetic chemicals for controlling insect pests of crop plants has resulted in hazardous effects causing serious problems including pest resistance, secondary pest outbreak, pest resurgence and 
environmental pollution. In view of this requirement, the present study was undertaken to find out the resistant/tolerant brinjal hybrids against shoot and fruit borer.

\section{Materials and Methods}

A field experiment was conducted in kharif and summer seasons during 2015-16 and 2016-17 at College of Agriculture, Vellayani, Trivandrum. Thirty days old seedlings having 8-10 $\mathrm{cm}$ height were transplanted into the main field at a spacing of $60 \mathrm{~cm} \mathrm{x} 75 \mathrm{~cm}$ during both seasons. The experiment was laid out in Randomized Block Design with four replications. Eleven genotypes were screened against brinjal shoot and fruit borer. The cultural practices except plant protection measures were followed as per the Package of Practices Recommendations of Kerala Agricultural University (KAU, 2011). Five plants per replication were tagged at random and observed for the incidence of shoot and fruit borer in each brinjal hybrid at 20 days interval from 60 DAT upto 100 DAT for shoot infestation and from 80 DAT upto 120 DAT for fruit infestation. The data on damage parameters collected from field experiment were subjected to statistical analysis.

The number of shoots affected by borer and total number of shoots per plant was recorded from five randomly selected plants and the percent of shoot borer infestation was worked out. The number of fruits affected by borer and total number of fruits harvested per plant was recorded from five randomly selected plants and the percent of fruit borer infestation was worked out. On the basis of mean shoot and fruit damage percentage all genotypes were categorized in different categories. Grades (1- Immune - 0\% infestation; 2Highly resistant - 1-10\% infestation; 3Moderately resistant - 11-20\%, 4-Tolerant21-30\%, 5- Susceptible - 31-40\%, 6-Highly susceptible - above $40 \%$ ) were assigned for the shoot and fruit damage based on the rating given by Mishra et al., (1988).

\section{Results and Discussion}

Shoot and fruit infestation of eleven brinjal hybrids at different days after transplantation has been presented in Tables 1 and 2 for kharif and summer seasons. During kharif season, the lowest shoot infestation was found in the hybrids Swetha x Vellayani local (15.97\%), Neelima (17.05 \%) and Wardha local $x$ Palakurthi local (19.39\%), being the pooled mean at 60, 80 and 100 DAT. The highest shoot infestation was found in the hybridsNBR-38 x Vellayani local (34.58 \%) and NBR-38 x Selection Pooja (32.9\%) as the pooled mean at 60, 80 and 100 DAT. During summer season, the lowest shoot infestation was found in the hybrids Swetha $\mathrm{x}$ Vellayani local $(16.83 \%)$, Wardha local x Palakurthi local $(18.36 \%)$, and Neelima $(18.75 \%)$ as pooled mean at 60, 80 and 100 DAT. The highest shoot infestation was found in the hybrids Surya xNBR-38 (40.53\%) and NBR$38 \times$ Selection Pooja (35.05\%) being the pooled mean at 60,80 and 100 DAT respectively.

During kharif season, the lowest fruit infestation as pooled mean was found in the hybrids Swetha x Vellayani local (23.89 \%), Neelima (24.19 \%) and Wardha local x Palakurthi local (27.28\%), at 80, 100 and 120 DAT. The highest fruit infestation was found in the hybrids NBR-38 x Selection Pooja (42.41\%), Wardha local x Surya (36.36\%), Surya $x$ Vellayani local (35.69 \%) and Wardha local $x$ Vellayani local $(35.52 \%)$ at 80,100 and 120 DAT. During summer season, the lowest fruit infestation was found in the hybrids Swetha x Vellayani local (17.25\%) and Neelima (19.38\%), Wardha local $x$ Swetha (29.24 \%) and Wardha local $x$ Palakurthi local (29.64\%) being the pooled mean at 80, 100 and 120 DAT. 
Table.1 Percentage of shoots and fruits damaged by shoot and fruit borer (L. orbanalis) at different intervals in kharif season

\begin{tabular}{|c|c|c|c|c|c|c|c|c|c|c|}
\hline \multirow[t]{2}{*}{ Geonotypes } & \multicolumn{5}{|c|}{ Shoot infestation \% } & \multicolumn{5}{|c|}{ Fruit infestation \% } \\
\hline & $\begin{array}{c}60 \\
\text { DAT }\end{array}$ & $\begin{array}{c}80 \\
\text { DAT }\end{array}$ & $\begin{array}{l}100 \\
\text { DAT }\end{array}$ & $\begin{array}{c}\text { Pooled } \\
\text { mean }\end{array}$ & $\begin{array}{l}\text { Gradin } \\
\mathrm{g}\end{array}$ & $\begin{array}{c}80 \\
\text { DAT }\end{array}$ & $\begin{array}{l}100 \\
\text { DAT }\end{array}$ & $\begin{array}{c}120 \\
\text { DAT }\end{array}$ & $\begin{array}{l}\text { Poole } \\
\text { d } \\
\text { mean }\end{array}$ & Grading \\
\hline $\begin{array}{l}\text { Wardha local x Palakurthi } \\
\text { local }\end{array}$ & 17.50 & 22.50 & 18.17 & 19.39 & MR & 21.67 & 30.67 & 29.50 & 27.28 & $\mathrm{~T}$ \\
\hline Wardha local x Surya & 35.00 & 27.92 & 28.00 & 30.31 & $\mathrm{~T}$ & 34.58 & 38.75 & 35.75 & 36.36 & S \\
\hline Wardha local x Swetha & 27.50 & 23.08 & 24.00 & 24.86 & $\mathrm{~T}$ & 31.16 & 33.08 & 32.58 & 32.27 & S \\
\hline $\begin{array}{l}\text { Wardha local x Vellayani } \\
\text { local }\end{array}$ & 32.50 & 28.75 & 25.67 & 28.97 & $\mathrm{~T}$ & 37.33 & 37.24 & 32.00 & 35.52 & $S$ \\
\hline $\begin{array}{l}\text { Palakurthi local x Vellayani } \\
\text { local }\end{array}$ & 42.50 & 28.75 & 23.00 & 31.42 & S & 33.33 & 31.16 & 29.66 & 31.38 & S \\
\hline Surya x NBR-38 & 37.50 & 29.17 & 29.00 & 31.89 & S & 36.65 & 35.17 & 32.08 & 34.63 & S \\
\hline Surya x Vellayani local & 27.50 & 27.50 & 25.00 & 26.67 & $\mathrm{~T}$ & 34.58 & 35.00 & 37.50 & 35.69 & S \\
\hline NBR-38 x Vellayani local & 40.00 & 34.74 & 29.00 & 34.58 & S & 33.32 & 31.42 & 29.16 & 31.30 & $\mathrm{~S}$ \\
\hline NBR-38 x Selection Pooja & 42.50 & 26.66 & 28.00 & 32.39 & $\mathrm{~S}$ & 42.49 & 44.83 & 39.91 & 42.41 & HS \\
\hline Swetha x Vellayani local & 12.50 & 20.41 & 15.00 & 15.97 & MR & 22.08 & 25.83 & 23.75 & 23.89 & $\mathrm{~T}$ \\
\hline Neelima & 15.00 & 19.16 & 17.00 & 17.05 & MR & 24.99 & 23.75 & 23.83 & 24.19 & $\mathrm{~T}$ \\
\hline Grand Mean & 30.00 & 26.24 & 23.80 & 26.68 & & 32.01 & 33.35 & 31.43 & 32.26 & \\
\hline C.D $(5 \%)$ & 8.18 & 6.24 & 5.66 & & & 7.27 & 5.65 & 6.26 & & \\
\hline
\end{tabular}

DAT - Days After Transplanting, MR- Moderately Resistant, T- tolerant, S- Susceptible, HS- Highly Susceptible.

Table.2 Percentage of shoots and fruits damaged by shoot and fruit borer (L. orbanalis) at different intervals in summer season

\begin{tabular}{|c|c|c|c|c|c|c|c|c|c|c|}
\hline \multirow[t]{2}{*}{ Geonotypes } & \multicolumn{5}{|c|}{ Shoot infestation \% } & \multicolumn{5}{|c|}{ Fruit infestation \% } \\
\hline & $\begin{array}{c}60 \\
\text { DAT }\end{array}$ & $\begin{array}{c}80 \\
\text { DAT }\end{array}$ & $\begin{array}{l}100 \\
\text { DAT }\end{array}$ & $\begin{array}{c}\text { Pooled } \\
\text { mean }\end{array}$ & $\underset{\mathrm{g}}{\text { Gradin }}$ & $\begin{array}{c}80 \\
\text { DAT }\end{array}$ & $\begin{array}{l}100 \\
\text { DAT }\end{array}$ & $\begin{array}{l}120 \\
\text { DAT }\end{array}$ & $\begin{array}{c}\text { Pooled } \\
\text { mean }\end{array}$ & Grading \\
\hline $\begin{array}{l}\text { Wardha local x Palakurthi } \\
\text { local }\end{array}$ & 15.00 & 21.42 & 18.67 & 18.36 & MR & 26.00 & 32.50 & 30.41 & 29.64 & $\mathrm{~T}$ \\
\hline Wardha local x Surya & 37.50 & 31.66 & 30.00 & 33.05 & $S$ & 32.91 & 36.25 & 33.75 & 34.30 & $\mathrm{~S}$ \\
\hline Wardha local x Swetha & 30.00 & 23.50 & 24.00 & 25.83 & $\mathrm{~T}$ & 26.99 & 30.66 & 30.08 & 29.24 & $\mathrm{~T}$ \\
\hline Wardha local x Vellayani local & 35.00 & 29.17 & 20.67 & 28.28 & $\mathrm{~T}$ & 35.66 & 36.66 & 32.50 & 34.94 & $\mathrm{~S}$ \\
\hline $\begin{array}{l}\text { Palakurthi local x Vellayani } \\
\text { local }\end{array}$ & 42.50 & 33.75 & 27.00 & 34.42 & S & 35.41 & 29.91 & 27.08 & 30.80 & $\mathrm{~T}$ \\
\hline Surya x NBR-38 & 42.50 & 42.08 & 37.00 & 40.53 & $\mathrm{~S}$ & 37.90 & 35.42 & 32.32 & 35.21 & $\mathrm{~S}$ \\
\hline Surya $\mathrm{x}$ Vellayani local & 32.50 & 29.58 & 28.00 & 30.03 & $\mathrm{~T}$ & 32.08 & 34.16 & 35.42 & 33.88 & $\mathrm{~S}$ \\
\hline NBR-38 x Vellayani local & 37.50 & 33.08 & 29.00 & 33.19 & S & 33.32 & 31.42 & 29.91 & 31.55 & $\mathrm{~S}$ \\
\hline NBR-38 x Selection Pooja & 42.50 & 31.66 & 31.00 & 35.05 & $\mathrm{~S}$ & 42.08 & 44.83 & 40.58 & 42.50 & HS \\
\hline Swetha $\mathrm{x}$ Vellayani local & 12.50 & 20.00 & 18.00 & 16.83 & MR & 16.92 & 17.21 & 19.25 & 17.79 & MR \\
\hline Neelima & 15.00 & 21.25 & 20.00 & 18.75 & MR & 19.16 & 18.08 & 20.92 & 19.38 & MR \\
\hline Grand Mean & 31.14 & 28.83 & 25.76 & 28.57 & & 30.76 & 31.55 & 30.20 & 30.84 & \\
\hline C.D. $(5 \%)$ & 7.20 & 3.79 & 4.87 & & & 3.92 & 2.62 & 4.80 & & \\
\hline
\end{tabular}

DAT - Days After Transplanting, MR- Moderately Resistant, T- tolerant, S- Susceptible, HS- Highly Susceptible. 
The highest fruit infestation was found in the hybridsNBR-38 x Selection Pooja (42.50\%), Surya xNBR-38 (35.21\%), Wardha local x Vellayani local (34.94 \%) and Wardha local $\mathrm{x}$ Surya $(34.30 \%)$ which is the pooled meanat 80,100 and 120 DAT.

Comparable range of fruit infestation was 20.23 to $45.61 \%$ reported by Jat et al., (2003), though they used different set of varieties/cultivars in their experiment. Malik et al., (2013) reported that shoot infestation varied from 0 to $20 \%$ but fruit infestation range was comparatively higher (14.18 to $53.19 \%$ ) among forty brinjal germplasm lines. Similarly, Devi et al., (2015) found 5.21 $\%$ to $28.27 \%$ fruit infestation in 18 eggplant varieties. Screening of brinjal genotypes against shoot and fruit borer infestation has been done by Mishra et al., (1988), Lit et al., (2002), Elanchezhyan et al., (2008) and Mannan et al., (2009), Javed et al., (2011) Singh et al., (2016) and Vethamoni et al., (2016) also.

On the basis of present studies, none of the cultivars was found to be free from the infestation of the brinjal shoot and fruit borer but considerable variation of infestation was recorded among different cultivars. The hybrids Wardha local $\times$ Palakurthi local, Swetha $\times$ Vellayani local and Neelima recorded minimum infestation of shoot and fruit borer during both kharif and summer seasons. Therefore, developing cultivars with natural resistance/ tolerance may decrease the cost of cultivation of the crop by decreasing pesticide application and is eco-friendly also.

\section{References}

Bhushan, S., Chaurasia, H. K. and Shanker, R. 2011. Efficacy and economics of pest management modules against brinjal shoot and fruit borer (Leucinodes orbonalis). The Bioscan. 6(4): 639-642.
Devi, P., Gawde, P. and Koshta, V. K. 2015. Screening of some brinjal cultivars for resistance to shoot and fruit borer (Leucinodes orbonalis Guenee). The Bioscan, 10(1): 247-251.

Elanchezhyan, K., Baskaran, R. K. and Rajavel, D. S. 2008. Field screening of brinjal varities on major pests and their natural enemies. J. Biopesticides. 1(2): 113-120.

Jat, K. L., Singh, S. and Maurya, R. P. 2003. Screening of brinjal varieties for resistance to shoot and fruit borer Leucinodes orbonalis (Guen.). Haryana J. Hort. Sci. 32(1): 152-153.

Javed, H., Mohsin, A., Aslam, M., Naeem, M., Amjad, M. and Mahmood, T. 2011. Relationship between morphological characters of different aubergine cultivars and fruit infestation by leucinodes orbonalis guenee. Pak. J. Bot. 43(4): 2023-2028.

KAU (Kerala Agricultural University). 2011. Package of practices Recommendations: Crops (14th Ed). Kerala Agricultural University, Thrissur, 334p.

Lit, M. T., Lapiz, R. V., Capricho, M. A. A., Urriza, R. P. and Humol, R. J. 2002. Yield and resistance of eggplant accessions/varieties against leafhopper, Amrascabigutulla Ishida and eggplant borer, Leucinodes orbonalis Guenee. Annual Scientific Meeting of the National Academy of Science and Technology. Manila, Philippines. 11-12 July 2002.

Malik, Y. P and Pal, R. 2013.Seasonal incidence of brinjal fruit and shoot borer (Leucinodes orbonalis Guen.) on different germplasm of brinjal in central U.P. Trends. Biosci. 6(4): 389-394.

Mannan, M. A., Begum, A. and Hossain, M. M. 2009. Screening of local and exotic brinjal varieties/ cultivars for resistance to brinjal shoot and fruit borer 
(Leucinodes orbonalis). Bangladesh $J$. Agril. Res. 34(4): 705-712.

Mishra, P. N., Singh, Y. V. and Nautiyal, M. C. 1988. Screening of brinjal varieties for resistance to shoot and fruit borer (Leucinodes orbonalis Guen.) (Pyralidae: Lepidoptera). South Indian Hort. 36(4): 188-192.

Shukla, A. and Khatri, S.N. 2010. Incidence and abundance of brinjal shoot and fruit borer Leucinoides orbonalis Guenee. The Bioscan. 5(2): 305-308.

Singh, J. P., Gupta, P. K., Chandra, U., Singh, V. K. and Singh, A. K. 2016. Field screening of brinjal germplasm against brinjal shoot and fruit borer (Leucinodes orbonalis Guenee.) at different stages of plant. Intl. J. Plant Prot. 9(1): 84-90.

Singh, S. P. and Nath, P. 2010. Cultural and biophysical management of brinjal shoot and fruit borer (Leucinodes orbonalis). A Biannual New letter of the (CIPS) in cooporation with the (IRAC) and (WRCC-60). 20: 42- 43.

Vethamoni, P. I. and Praneetha, S. 2016. Growth and yield attributes with shoot and fruit borer resistance in parents and $\mathrm{F}_{1}$ hybrids of brinjal. Madras. Agric. J. 103(1/3): 83-86.

\section{How to cite this article:}

Vinay Kavishetti and Lekha Rani, C. 2018. Screening of Brinjal Hybrids for Resistance to Brinjal Shoot and Fruit Borer, Leucinodes orbonalis (G.). Int.J.Curr.Microbiol.App.Sci. 7(02): 2458-2462. doi: https://doi.org/10.20546/ijcmas.2018.702.299 